\title{
政府統計データを用いた薬局に従事する薬剤師の分布に関する調査
}

\author{
矢島聖子, ${ }^{a}$ 島内あかり, ${ }^{a}$ 堺 千紘, ${ }^{a}$ 横山 聡, $^{a}$ 伊野陽子, ${ }^{a}$ \\ 松永俊之, ${ }^{b}$ 寺町ひとみ, ${ }^{c}$ 中村光浩, ${ }^{d}$ 井口和弘 ${ }^{*, a}$
}

\section{Survey of the Distribution of Community Pharmacists Using Government Statistics}

\author{
Satoko Yajima, ${ }^{a}$ Akari Shimauchi, ${ }^{a}$ Chihiro Sakai, ${ }^{a}$ Satoshi Yokoyama, ${ }^{a}$ Yoko Ino, ${ }^{a}$ \\ Toshiyuki Matsunaga, ${ }^{b}$ Hitomi Teramachi, ${ }^{c}$ Mitsuhiro Nakamura, ${ }^{d}$ and Kazuhiro Iguchi ${ }^{*, a}$ \\ ${ }^{a}$ Laboratory of Community Pharmacy, Gifu Pharmaceutical University; 1-25-4 Daigakunishi, Gifu 501-1196, \\ Japan: 'baboratory of Biochemistry, Gifu Pharmaceutical University; 1-25-4 Daigakunishi, Gifu 501-1196, \\ Japan: 'Laboratory of Clinical Pharmacy, Gifu Pharmaceutical University; 1-25-4 Daigakunishi, \\ Gifu 501-1196, Japan: and ${ }^{d}$ Laboratory of Drug Informatics, Gifu Pharmaceutical
} University; 1-25-4 Daigakunishi, Gifu 501-1196, Japan.

(Received December 14, 2017; Accepted March 9, 2018)

\begin{abstract}
In Japan, within the background of a progressively aging society, a community general support system is gradually being established. Under this system, community pharmacists are expected to expand their activities in local communities. Here, we surveyed the distribution of community pharmacists in Japan by using government statistics. We found that there are 153 towns/villages without community pharmacists, which is about six times the number of towns without physicians (26 towns/villages). The number of community pharmacists per 100000 population was correlated with the population of the municipality. There was a significant difference in the number of community pharmacists per 100000 population between depopulated and non-depopulated areas. A multiple regression analysis revealed that population, financial capability index, and number of physicians per 100000 population were positively associated with the number of community pharmacists per 100000 population in a given municipality. We hope that the survey provides useful information about future issues facing community pharmacy in a community general support system.
\end{abstract}

Key words_— community pharmacist; distribution; depopulated area; government statistics

\section{緒言}

日本では諸外国に類を見ないスピードで高齢化が 進展しており，2025 年には 75 歳以上の人口が 2000 万人を超え，2055 年には全人口の約 $26 \%$ が 75 歳以 上となることが予想されている. ${ }^{1)} 75$ 歳以上の約 3 割が要支援・要介護認定者であること年からも，今 後の介護負担と在宅療養支援の必要性の増加は論を 俟たない。このような現状を見据え，介護度の高い 高齢者においても各地域における生活が成立するよ う, 「地域包括ケアシステム」が 2025 年を目途に構 築されつつある. ${ }^{3)}$ 地域包括ケアシステムは, 医 療，介護，及び生活支援等を一体的に提供すること

$a$ 岐阜薬科大学薬局薬学研究室, ${ }^{b}$ 岐阜薬科大学生化学 研究室, c岐阜薬科大学病院薬学研究室, $d$ 岐阜薬科大 学医薬品情報学研究室

*e-mail: iguchi@gifu-pu.ac.jp
を目的としており，医療従事者，介護従事者，行政 や地域住民を始めとした多くの人的資源とその連携 の下で成立する. ${ }^{3}$ 薬局に従事する薬剤師（以下, 薬局薬剤師）は，この地域包括ケアシステムを構成 する一員としての活躍が求められており, 具体的に は，24 時間対応や在宅対応を含めたかかりつけ薬 局・薬剂師としての働きや, 健康サポート薬局の機 能の提供体制の充実が必要不可欠とされる. ${ }^{4}$

薬局は，平成 28 年度衛生行政報告例（厚生労働 省）によると約 5 万 9 千店舗，薬局薬剂師は，平成 26 年 医師・歯科医師・薬剂師調査（厚生労働省） によると約 16 万人であり, ともに前回調査に比べ 増加しているが, 一方で, 薬局薬剤師の地域偏在に ついて，都市部での集中傾向が指摘されている. ${ }^{5)}$ 前述のように，地域包括ケアシステムを支えるため に, 日常生活圈域で医療従事者の存在が必要とされ る中, 地方における薬局薬剤師不足は好ましくな 
い.また，医師の偏在や不足の解消は，当然ながら 地域医療を保つ上で必須であり，長きに渡り課題と して認識されている。すなわち，地域間の医師数の 偏り（地理的遍在）に加え，特定の診療科の医師の 不足（診療科偏在）があり，厚生労働省の「医療従 事者の需給に関する検討会」の医師需給分科会にお いても議論がなされている. ${ }^{6-8)}$ 一方で，薬局薬剤 師については，その分布の特徵について示した報告 は少ない，そこで今回は，各種政府統計デー夕によ り，薬局薬剂師数の地域分布の現状を明らかにする ことを目的として調查を行った。また，医療施設医 師数の現状との比較により, 薬局薬剂師の分布の特 徵を明らかにすることを試みた。

\section{方法}

1. 統計データ 政府統計デー夕は, 「平成 26 年 医師・歯科医師・薬剂師調查（厚生労働省）」, 「平成 27 年 住民基本台帳に基づく人口，人口動態 及び世帯数（総務省）」,「平成 26 年度地方財政状況 調査（総務省）」，及び「平成 27 年国勢調査（総務 省統計局)」を使用した。なお，「平成 26 年 医師・ 歯科医師・薬剂師調査（厚生労働省）」は 2014 年 12 月 31 日現在，「平成 27 年 住民基本台帳に基づ く人口，人口動態及び世帯数（総務省）」は 2015 年 1 月 1 日現在，「平成 26 年度地方財政状況調査（総 務省)」は平成 26 年度決算（2015 年 3 月 31 日）に 基づいた調査データである。市区町村圈域について は 2014 年末時点の圏域に固定化した。すべての政 府統計デー夕は，独立行政法人統計センターの政府 統計の総合空口 e-Stat のホームページ (https:// www.e-stat.go.jp/） より 2017 年 9 月にダウンロー ドした。

2. データセット 薬局薬剂師数及び医療施設 医師数は「平成 26 年 医師・歯科医師・薬剂師調査」 の中のそれぞれ「薬局の従事者総数（開設者又は法 人の代表者と勤務者の計)」及び「医療施設の従事 者総数（病院の従事者総数と診療所の従事者総数の 計)」を使用した.

人口総数と年齢階級別人口は，「平成 27 年 住民 基本台帳に基づく人口，人口動態及び世帯数（総務 省)」の中の「市区町村別人口」と「市区町村別年 齢階級別人口」を使用した。ここで，住民基本台帳 に基づく人口は，住民票を基に集計された人口であ
り，昼間人口を反映していない。そのため，東京都 中心部などの昼夜間人口比率が大きい地域では，単 位人口当たりの医療従事者数が極端に高值を示し, 実状を反映しない。したがって，平成 27 年国勢調 查（総務省統計局）の昼夜間人口比率を用い，都心 5 区（千代田区，中央区，港区，渋谷区，新宿区） を除くことができる基準值として 2 倍を設定した. 昼夜間人口比率が 2 倍以上の市区町村は 9 であり, 都心 5 区に加え，福島県の避難指示区域内の町村が 含まれた。また，福島県の帰宅困難区域を含む 4 町 は，昼夜間人口比率が非表示であり，同様にデー夕 セットから除外した。 なお，逆に，昼夜間人口比率 が小さい地域に関し，当該比率が $1 / 2$ 以下の市区町 村は存在しなかった。本解析の結果は，上述の合計 13 の特別区及び町村を除外したため，通勤や通学 者が集まる従業地や通学地の現状を反映しきれてい ない可能性が少なからず存在している.

また，過疎地域は，過疎地域自立促進特別措置法 第 2 条 1 項の過疎地域の要件に従い, 2017 年 4 月 1 日 において過疎地域に指定されている 644 市町村とし, 非過疎地域は，過疎地域の市町村と同法第 33 条 1 項及び 2 項の合併の場合の取扱いにより 2017 年 4 月 1 日においてみなし過疎地域若しくは一部過疎 地域に指定された市町村を除いた 914 市区町村とし た.

3. モザイク図人口 10 万対薬局薬剤師数及 び人口 10 万対医療施設医師数と地域の人口特性の 関係についてモザイク図を作成した。モザイク図 は，長方形の面積が分析対象の比率を示すグラフで ある。人口特性は，標準偏差分類により 4 階級 （I から IV）に分類した [Figs. 1(c)-(e)]。また， 人口 10 万対薬局薬剂師数及び人口 10 万対医療施設 医師数は， 10 万人当たりの人数が「0」であった町 村を 1 つの階級とし，さらに「0」以外の市区町村 を標準偏差分類により 4 階級に分類し，全体で 5 階 級（0から 4）とした [Figs. 1(a) and (b)].

4. ジ二係数市区町村人口に対する薬局薬剤 師数のジ二係数を求めた。 人口 10 万対薬局薬剤師 数が小さい順に市区町村を配置したときの人口の累 積相対度数を横軸, 薬局薬剤師数の累積相対度数を 縦軸とし，ローレンツ曲線を得た。ジ二係数は, ローレンツ曲線と均等配分線で囲まれた面積の割合 から算出した。 
5. 重回帰分析人口 10 万対薬局薬剤師数に 独立して影響を及ぼす因子として，人口総数，老年 人口割合, 生産年齢人口割合, 財政力指数, 人口 10 万対医療施設医師数について，総当たり法によ り変数選択を実施した。モデルの最適化は，有限修 正された赤池情報量規準 (corrected Akaike's information criterion; AICc) に基づいて行った。 また, 独立変数間の強い相関は多重共線性を生じるため, Spearmanの順位相関係数を用いて，因子間の相関 係数が 0.7 以上となる項目がないことを確認した. なお，重回帰モデルの有意性の検定は分散分析にて 行い, 多重共線性は分散拡大要因 (variance inflation factor；VIF）を用いて評価した.

6. 統計解析 過疎地域と非過疎地域における 人口 10 万対薬局薬剂師数及び人口 10 万対医療施設 医師数の分布の比較は Mann-Whitney $U$ 検定にて 解析し, 統計学的有意水準は 5\%とした。統計ソフ トは JMP ${ }^{\circledR} 12$ (SAS Institute Inc., Cary) を用いた。

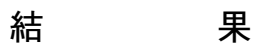

各市区町村の人口 10 万対薬局薬剤師数, 人口 10 万対医療施設医師数，人口総数，老年人口割合 $(65$ 歳以上人口/全人口), 及び生産年齢人口割合（15 歳から 64 歳の人口/全人口）の分布について, Fig. 1 にヒストグラムを示す。人口 10 万対薬局薬剂師 数及び人口 10 万対医療施設医師数は，各市区町村 の薬局薬剤師数，医療施設医師数及び人口総数を用 いて算出した。なお, 各分布の点線は Fig. 3 のモ ザイク図の階級の境界である.

すべての市区町村の人口 10 万対薬局薬剂師数及 び人口 10 万対医療施設医師数を昇順に並べた結果 を Fig. 2 に示した。 全 1728 市区町村のうち，薬局 薬剂師数若しくは医療施設医師数が 0 人の自治体は それぞれ 153 町村と 26 町村であり，医療施設医師 の存在しない町村数に比べ, 薬局薬凨師が存在しな い町村は, 約 6 倍であった.

次に, 人口 10 万対薬局薬剂師数と人口総数, 老 年人口割合，及び生産年齢人口割合の関係を視覚的 に把握するために，モザイク図を作成した。 その結 果, Fig. 3 (a) に示すように, 人口総数の増加に伴 い人口 10 万対薬局薬剤師数が増加する傾向である ことが明らかになった，さらに，人口 10 万対薬局 薬剂師数は，市区町村の生産年齢人口割合との間に
おいて同様の傾向を示し，市区町村の高齢化人口割 合との間では，逆に，その割合の増加に伴い人口 10 万対薬局薬剂師数が減少する傾向であった。な お，薬局薬剂師数が 0 人の階級はすべて人口総数の 最も少ない階級に属していた。 また，人口 10 万対 医療施設医師数に関し，人口総数，老年人口割合及 び生産年齢人口割合の間に人口 10 万対薬局薬剂師 数の場合と同様な傾向が認められた [Fig. 3(b)].

人口 10 万対薬局薬剤師数と人口は関連している 傾向であったため, 過疎地域と非過疎地域に分類し て解析した. その結果, Fig. 4 に示すように, 人口 10 万対薬局薬剂師数は, 過疎地域に比べ非過疎地 域において有意に高值を示した $(p<0.0001)$ 。ま た，人口 10 万対医療施設医師数についても，人口 10 万対薬局薬剤師数と同様, 過疎地域と非過疎地 域の間に有意な差が認められた。

次に, 薬局薬剤師数及び医療施設医師数の市区町 村間での偏りの程度についてジ二係数により評価し た. ジ二係数は，0（完全に平等）から 1 （完全に 不平等）の数值で表される指標である. Figure 5 に 示すように，薬局薬剤師数の市区町村間での偏り （ジ二係数：0.15）は，医療施設医師数の場合（ジ 二係数：0.28）に比べて小さい結果であった。 ま た，過疎地域と非過疎地域に分けた場合，薬局薬剂 師数は，過疎地域に指定されている市区町村間（ジ 二係数：0.27）に比べ, 非過疎地域（ジ二係数： 0.14）では小さかった。一方で，医療施設医師数 は, ジ二係数が過疎地域で 0.30 , 非過疎地域で 0.29 であり，いずれの地域間においても同程度で あった。

人口 10 万対薬局薬凨師数に影響する要因とし て, 人口総数, 老年人口割合, 生産年齢人口割合, 過疎地域の要件である財政力指数，及び人口 10 万 対医療施設医師数を候補とした。すべての独立変数 が含まれるモデルが最小の AICc 值を与えたが，老 年人口割合と生産年齢人口割合において VIF 值が 高值を示した。そこで，得られた AICcに基づき， 老年人口割合と生産年齢人口割合のうち, 老年人口 割合を除外した。さらに老年人口割合を除いた 4 つ の独立変数からなるモデルでは，生産年齢人口割合 の標準偏回帰係数は 0.038 で低值を示し，また $p$ 值 は 0.17 であったことから，生産年齢割合について 除く判断をした。最終的に，独立変数として人口総 
a)

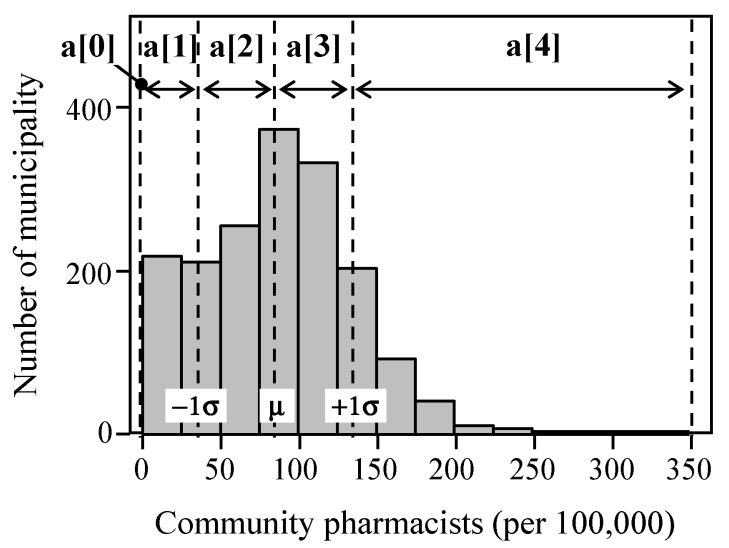

c)

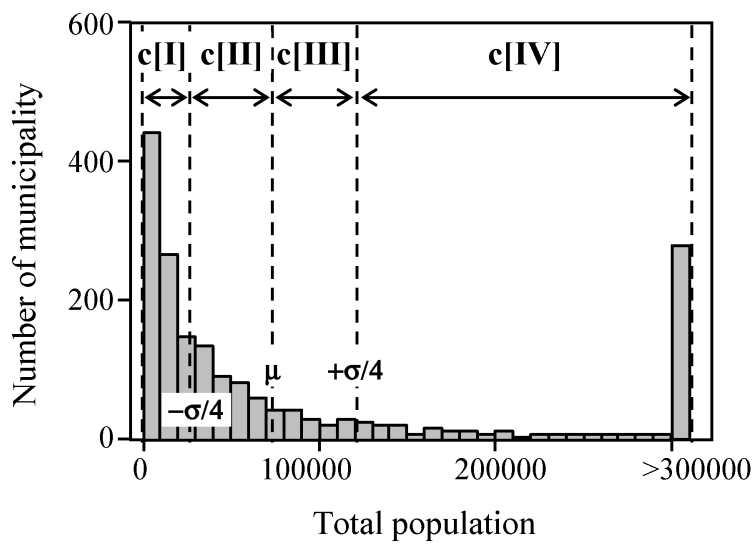

e)

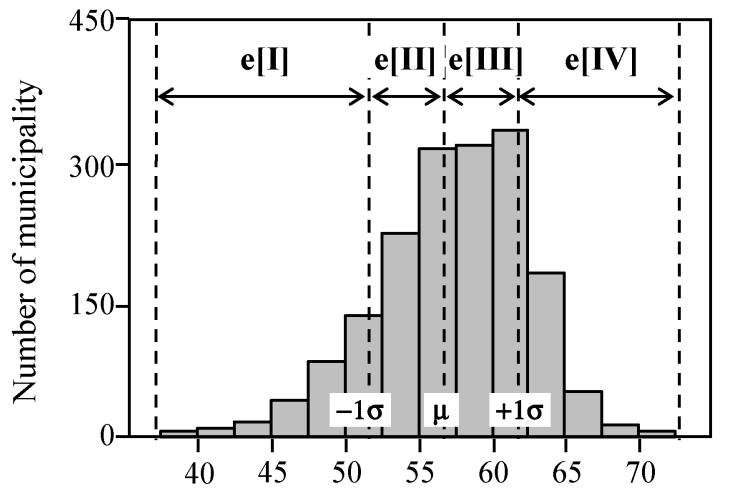

Working age population ratio (\%) b)

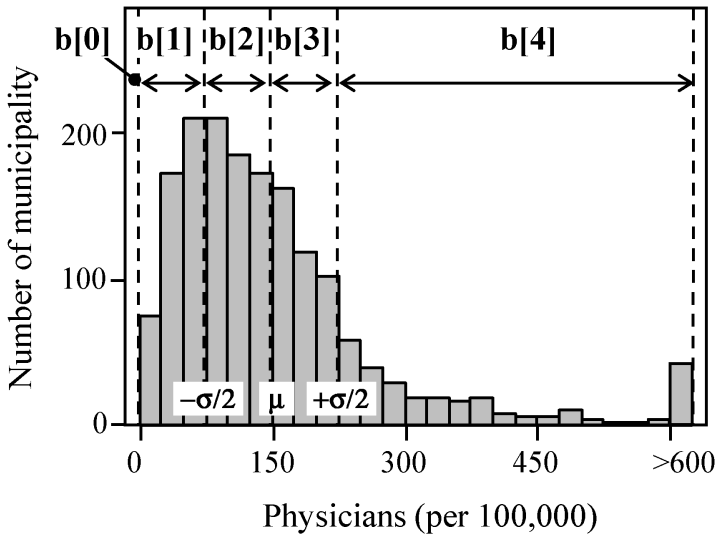

d)

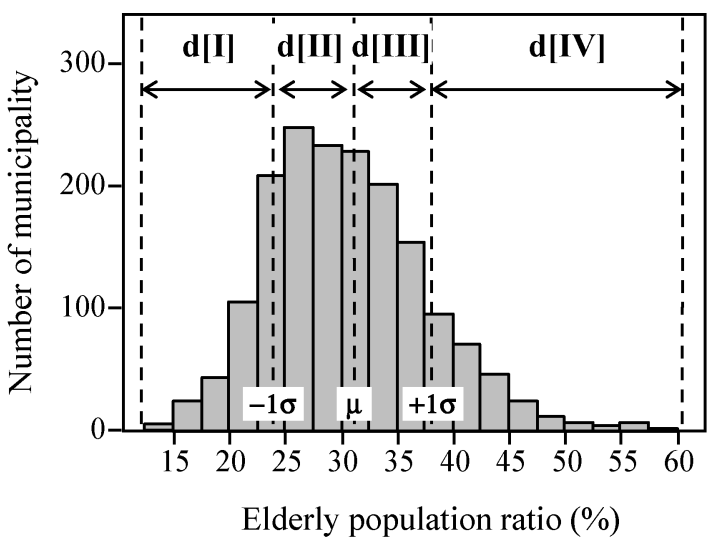

Fig. 1. Histograms of (a) the Number of Community Pharmacists per 100000 Population, (b) the Number of Physicians per 100000 Population, (c) Total Population, (d) Elderly ( $\geq 65$ Years) Population Ratio and (e) Working Age (15-64 years) Population Ratio

Dotted lines show the border of groups created by S.D. classification. $\mu$, mean; $\sigma$, S.D. 
a)

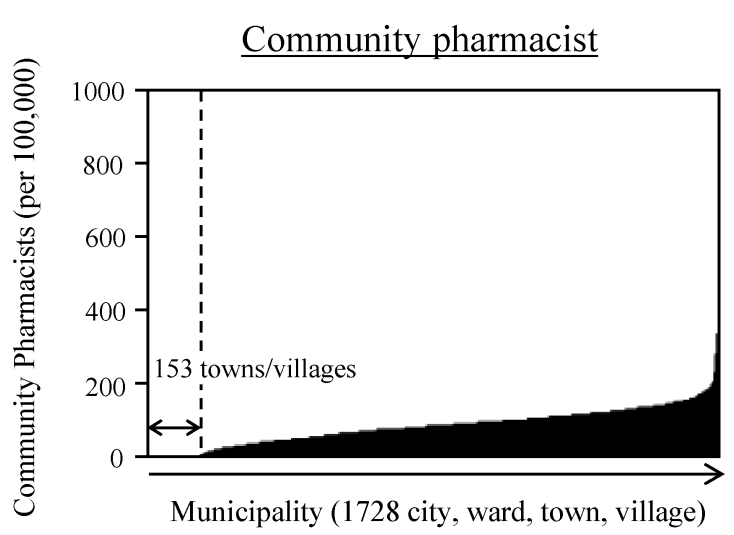

b)

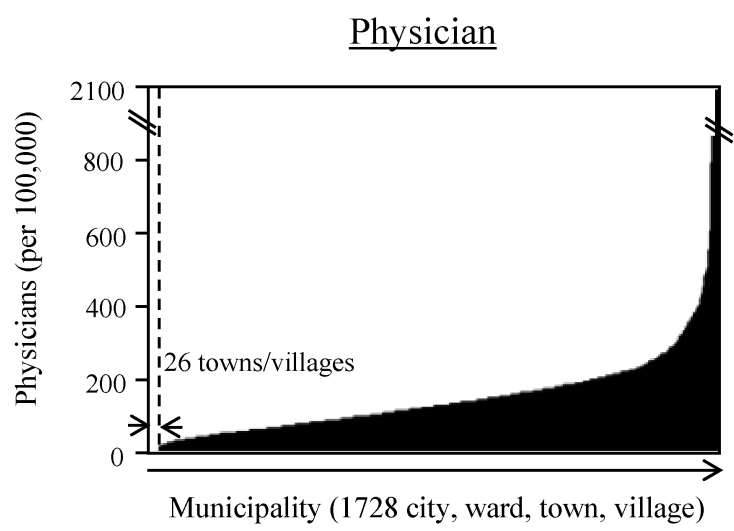

Fig. 2. The Number per 100000 Population

(a) Community pharmacists per 100000 population, (b) physicians per 100000 population. The municipalities (city, ward, town, or village, $n=$ 1728) are arranged in ascending order depending on the number per population.

数，財政力指数，人口 10 万対医療施設医師数を選 択し，重回帰分析を行った（Table 1)。なお，各独 立変数の VIF は 5 未満であり，多重共線性の問題 はないと考えた。これら 3 種の独立変数を使用して 作成した重回帰モデルは有意であった（ $p<$ 0.0001)。標準偏回帰係数は人口 10 万対医療施設医 師数が最も大きく $0.39 \quad(p<0.0001)$ ，ついで財政 力指数が $0.31 \quad(p<0.0001)$, 人口総数 $0.14 （ p<$ 0.0001）であり，いずれも正の影響を示した.

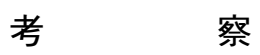

本調査では，政府統計デー夕を用い，全国の市区 町村における薬局に従事する薬剤師数と医療機関に 従事する医師数の現状を分析した。その結果，人口 10 万対薬局薬剂師数と人口 10 万対医療施設医師数 は，市区町村人口の大きさに従った偏りの存在が考 えられたものの，その程度には差があることが推察
された，すなわち，全市区町村における薬局薬剤師 の分布は，ジ二係数で評価した場合，医療施設医師 の分布の偏りに比べて小さかった．さらに，過疎地 域に分類される市町村のみを考えた場合の薬局薬剤 師の分布について，医療施設医師の分布と同程度の 偏りであることを見い出した．また，人口の少ない 地方自治体において，医師は存在するが薬局薬剤師 は存在しない町村が数多く上るという地域分布の特 徵を明らかにした。

医療施設医師の存在しない自治体数に比べ，薬局 薬剤師が存在しない自治体が著しく多数であった理 由を説明できる結果は持ち合わせていないものの, 以下のように推察している，すなわち，医師の確保 を目的とした様々な施策が，国，各都道府県を始め 多くの自治体により講じられており，医療施設医師 が存在しない自治体数が低減している可能性が考え られる．例えば，大学卒業後に一定期間のへき地勤 務を指定する自治医科大学の制度は，医療施設医師 の偏在の低減に有効である旨の報告がある. ${ }^{9}$ 一 方，地方での薬局薬剤師確保のため，企業における 取り組みとしては，職場環境や給与体系の改善に取 り組むような例はあるものの, 薬局薬剤師の分布に 介入することを目的とした国や地方自治体による取 り組みは，われわれの知る限り存在しない。さら に，地域住民に薬局薬剂師の業務や役割について十 分に理解されていないため，地域住民が地域に薬局 がない場合でも不便を感じないと考えているとの報 告も興味深い. ${ }^{10)}$ 薬局薬剤師は在宅訪問による服薬 管理を始め，地域包括ケアシステムを構成する一員 としての役割が期待されている，地域包括ケアシス テムに位置する薬局薬剤師が存在しない場合, 薬の 専門家ではない看護師などの他職種が在宅での薬の 管理を担っている実状もある.11) これは，患者の不 利益も然ることながら，他職種の負担増による本来 の業務への悪影響を与えることになると思われる. 地域包括ケアシステムの充実に向け，地方での薬局 薬剂師の確保に向けた取り組みの広がりに期待した い.

ジニ係数は所得分配の不平等さを測る指標であ り，医療資源の偏在の評価においても使用され る. 12) 例えば，診療所医師の人口に対するジ二係数 は 2006 年において $0.34,{ }^{7)}$ 新潟県の市町村を単位 とした医師数では 2002 年において $0.411,{ }^{13)}$ 全国 
a)
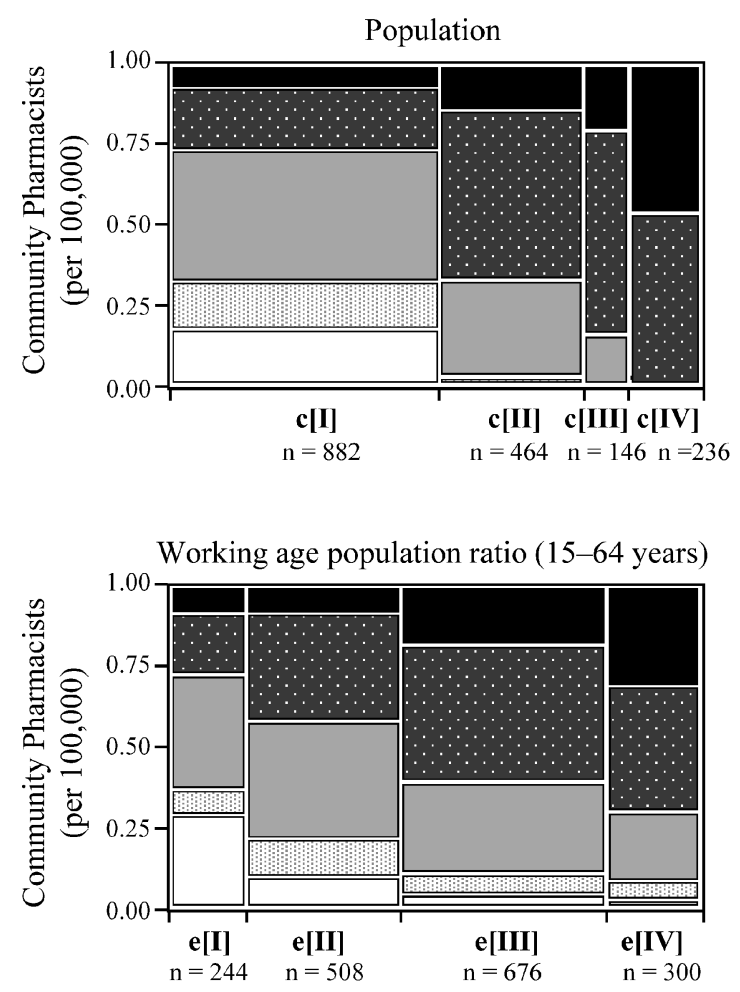

Elderly population ratio ( $\geq 65$ years)

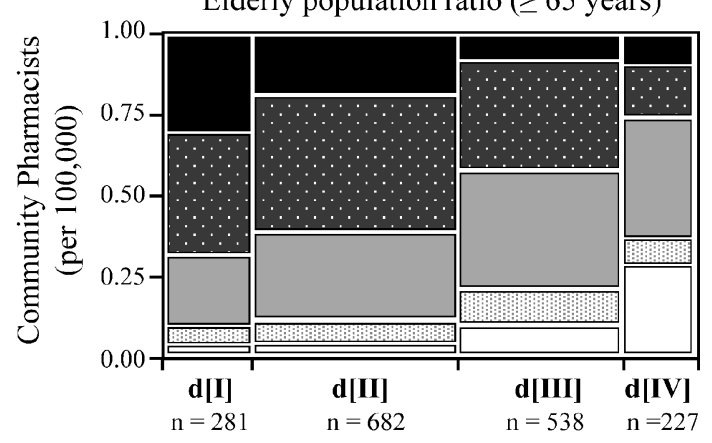

\section{Community pharmacists} per 100,000 population

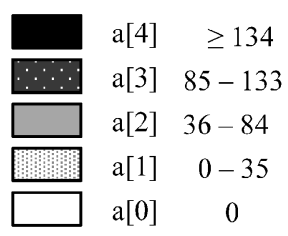

b)

$\underline{\text { Physician }}$
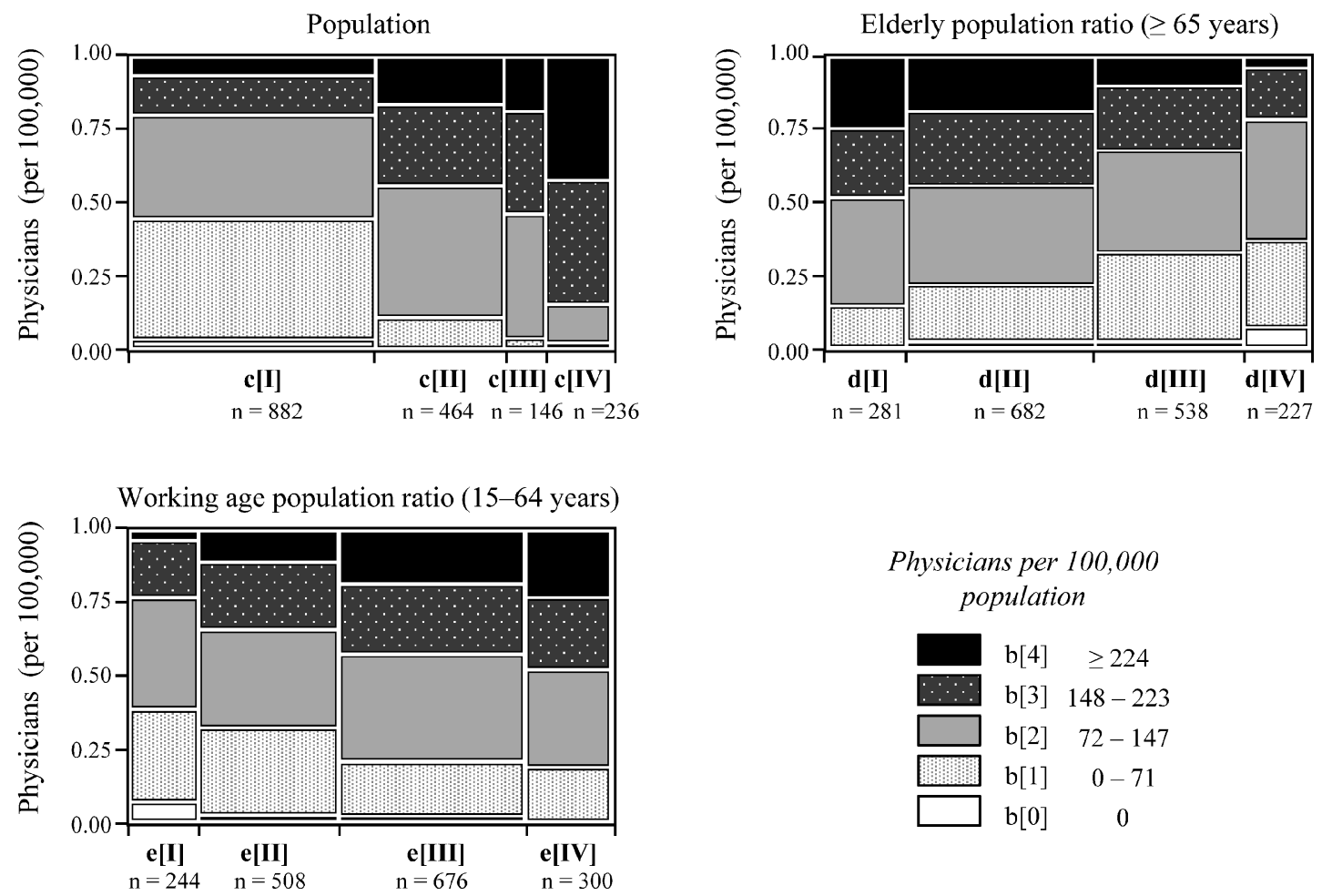

Fig. 3. Mosaic Plots of the Number per 100000 Population by Total Population, Elderly Population Ratio, or Working Age Population

(a) Community pharmacists per 100000 population, (b) physicians per 100000 population. Grouping is shown in Fig. 1. 
a)

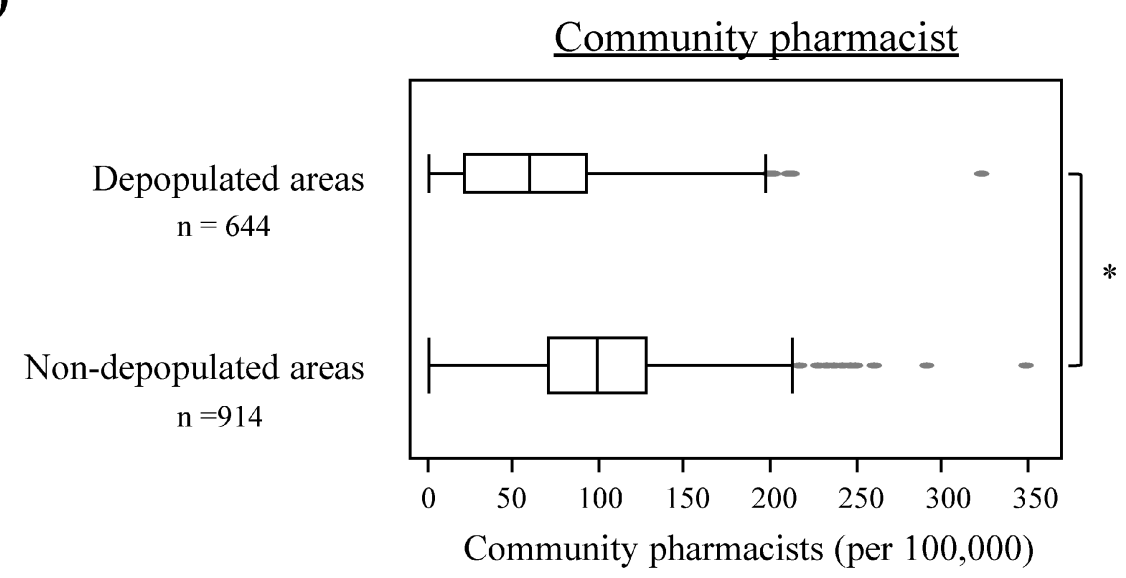

b)

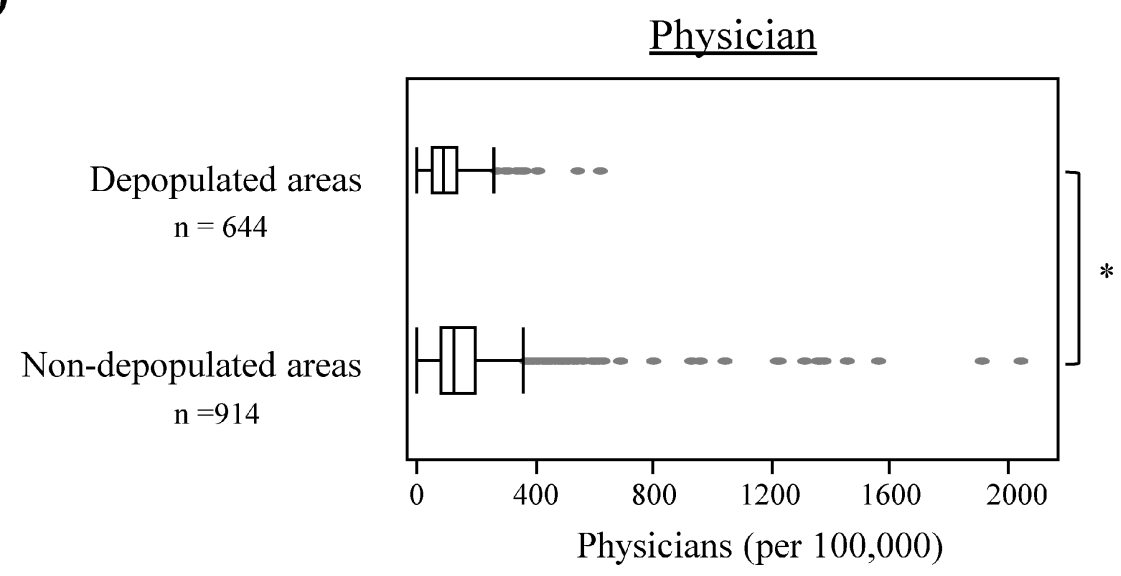

Fig. 4. Box Plots of the Number per 100000 Population in Depopulated Areas and Non-depopulated Areas (a) Community pharmacists per 100000 population, (b) physicians per 100000 population. Mann-Whitney $U$ test, ${ }^{*} p<0.001$.

の二次医療圏を単位とした看護師数では 2010 年に おいて $0.155,{ }^{14)}$ 北海道の二次医療圈を単位とした 診療放射線技師では 2014 年において 0.078 15 ) な ど，複数の報告でジニ係数が算出されている，一方 で，ジニ係数の数值は相対的な指標であり，実用的 な評価においてはその数值が 0.4 を超えると「高い 不均一」であるとする目安が示されているもの の, ${ }^{12)}$ 偏在を規定することができる明確な数值は存 在しない。本調査では, 全市区町村における薬局薬 剂師数のジ二係数 $(0.15)$ は, 医療施設医師数のジ 二係数 (0.28) に比べ小さいことを示した. 上述の 理由から, この数值のみをもつて薬局薬剤師の偏在 の有無を判断することはできないものの, 全国の市 区町村を単位とした場合の薬局薬剤師は，地域偏在 が存在するとされる医師 ${ }^{6-8)}$ に比べ，より平等に分 布していると考えられる.

興味深いことに，過疎地域と非過疎地域に分けて
評価した場合，医療施設医師数のジ二係数は，過疎 地域（0.30），非過疎地域（0.29）であり，同程度 の值を示す一方, 薬局薬剤師では, 非過疎地域 （0.14）は過疎地域（0.27）に比べて著しく低值で あった。過疎地域に該当する市町村の総人口は人口 総数の $6.9 \%$ であり, 市区町村全体から算出したジ 二係数は, 非過疎地域（人口総数の $76.3 \%$ ）の值 の影響が大きい。したがって，薬局薬剤師の全市区 町村におけるジ二係数は, 非過疎地域のジ二係数の 影響を受けて低值を示したと考えられる．また，過 疎地域の中で考えた場合, 薬局薬剤師のジ二係数 は，一般的に偏在が存在するとされる医療施設医師 数のジ二係数と同程度の值であったことより, 過疎 地域の中での薬局薬剤師は，人口に対して不平等に 存在していると考えられた。すなわち，過疎地域に 該当する市町村間において, 人口対薬局薬剤師数の 多頞が大きいことが示唆された. 
a)

All (Community pharmacist)

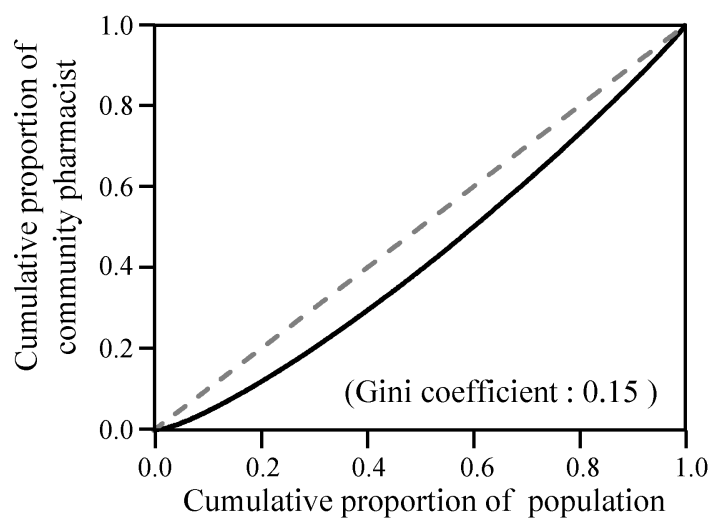

c)

Depopulated areas (Community pharmacist)

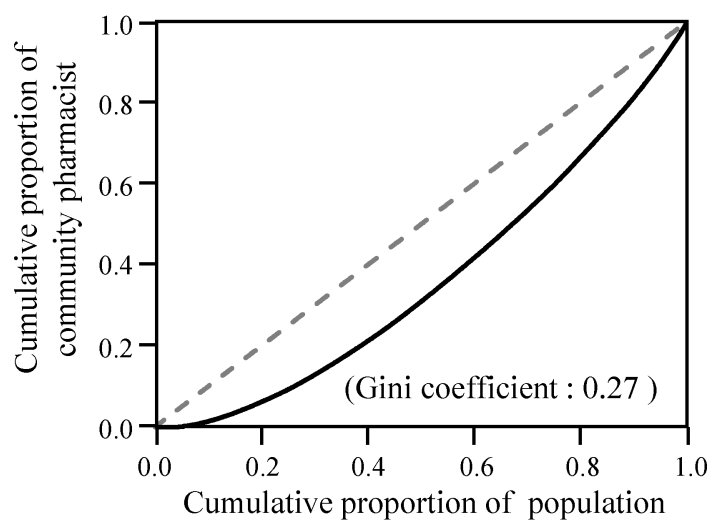

e)

Non-depopulated areas (Community pharmacist)

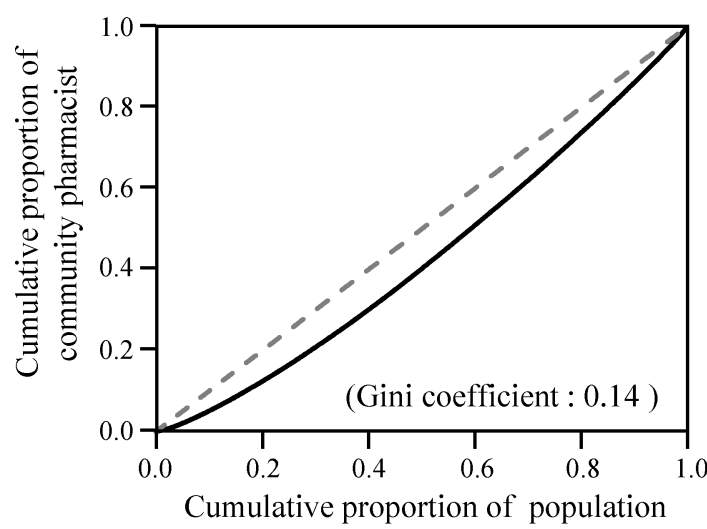

b)

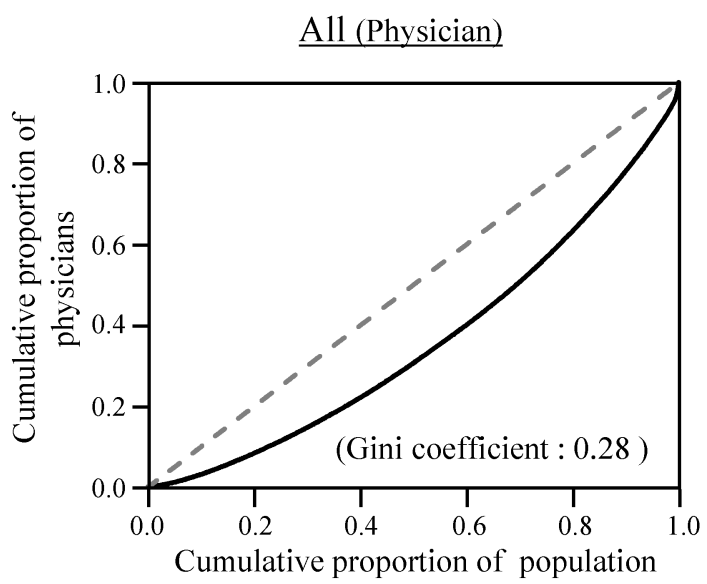

d)

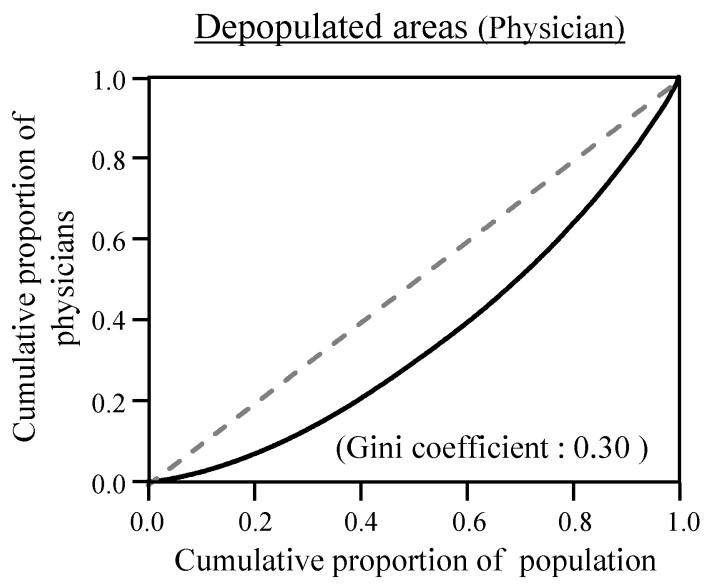

f)

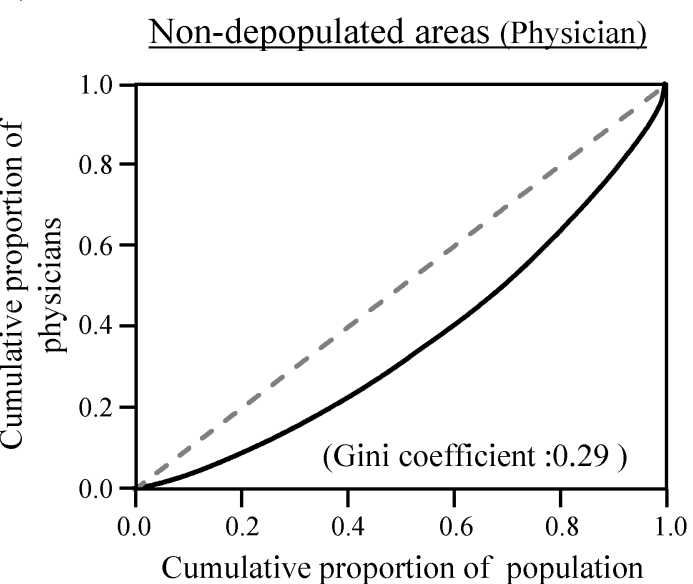

Fig. 5. Lorenz Curve and Gini Coefficient for (a, b) All Areas, (c, d) Depopulated Areas, (e, f) Non-depopulated Areas (a, d, e) Community pharmacist, (b, d, f) physician.

薬局薬剤師数は，医療施設医師数と同様，人口と の関連が観察された。すなわち，人口 10 万対薬局 薬剂師数と人口 10 万対医療施設医師数はともに, 人口総数，老年人口割合及び生産年齢人口割合と相
関傾向が認められた。 また，過疎地域と非過疎地域 に分類したとき，人口 10 万対薬局薬剤師数や人口 10 万対医療施設医師数は，過疎地域に比べ非過疎 地域において有意に高値を示した。医療従事者は大 
Table 1. Multiple Regression Analysis for the Number of Community Pharmacists per 100000 Population

\begin{tabular}{lcccc}
\hline \hline Variable & $\begin{array}{c}\text { Partial } \\
\text { regression } \\
\text { coefficient }\end{array}$ & $\begin{array}{c}\text { Standard par- } \\
\text { tial regression } \\
\text { coefficient }(\beta)\end{array}$ & $p$ value & VIF \\
\hline Intercept & 37.67 & 0.00 & $<0.0001$ & \\
$\begin{array}{l}\text { Population } \\
\text { Physicians per }\end{array}$ & $3.56 \times 10^{-5}$ & 0.14 & $<0.0001$ & 1.14 \\
$\begin{array}{l}\text { 100000 population } \\
\text { Financial capability }\end{array}$ & 0.13 & 0.39 & $<0.0001$ & 1.07 \\
index & 53.44 & 0.31 & $<0.0001$ & 1.15 \\
\hline
\end{tabular}

$\mathrm{R}^{2}=0.363$, Adjusted $\mathrm{R}^{2}=0.362$.

都市志向や大病院志向を有している場合が多いとさ れる. ${ }^{15,16)}$ 医師がへき地での勤務を望まない理由と して，例えば，知識技術の向上困難，過重労働，生 活が不便，子弟教育の支障等があると報告されてい る. ${ }^{16,17)}$ また，へき地における人口減少や患者の大 病院志向が患者数減少を来たすことが予想され，医 療機関の経営の面においても不利に㗢く. ${ }^{16)}$ 同種の 懸念は薬局薬剤師の勤務や薬局経営においても容易 に推測されるものであり, 薬局薬剤師数と人口との 関連性の理由の 1 つであると考えられる.

重回帰分析の結果，人口 10 万対薬局薬剤師数に 最も影響を与える因子は，人口 10 万対医療施設医 師数であった．面分業の薬局は全体の $23.3 \%$ に過 ぎないことが報告されており, ${ }^{18)}$ この結果は，多く の調剂薬局が医療施設の周囲に存在していることが 一因であると示唆される. 一方で, 人口 10 万対医 療施設医師数は今回のモデルの中間变数に位置して いる可能性は否定できない. 人口 10 万対医療施設 医師数をモデルから除いた場合, 自由度調整済み $\mathrm{R}^{2}$ 值は 0.22 に減じ, 標準偏回帰係数は, 財政力指 数が $0.37(p<0.0001)$, 人口総数 $0.19(p<0.0001)$ となった（成績未掲載）。また，本調査の重回帰分 析で独立変数として扱うことのできた因子以外に も, 薬局薬剤師数に関連が推察される因子として, 例えは，医薬分業率を挙げることができる，日本薬 剂師会が公表する各都道府県の医薬分業率のデー 夕19）に基づき，分業率の下位 30\%に当たる 14 府県 を抽出したところ, 人口当たりの薬局薬郕師数が全 国平均よりも多い自治体は 3 府県のみであった。本 調查は, 市区町村単位のデータについて扱つたた め，医薬分業率を重回帰分析に含めることはできな いものの, これらの要因を考慮に加えた更なる結果
は興味深い。

本調査の結果は, 人口に対する薬局薬剤師の分布 の実態を示すものであり, 地方や都市部での薬局薬 剂師数が必要数に対して充足か否かについては言及 することができない。一方で，院外処方せん枚数の デー夕19)を使用し, 薬局薬剤師 1 人当たりの院外処 方せん枚数の算出を試みた (成績未掲載)。これは, 薬局薬剂師数が対応する院外処方せん取扱枚数が少 ないほど業務負担が小さいこと（充足している可能 性）を示す 1 つの指標になり得る．その結果，過疎 地域市町村数の比率 20 が高い上位 30\%（14 道県） 中, 薬局薬剤師 1 人当たりの院外処方せん枚数が全 国平均值よりも少ない自治体は 1 県のみであった. また, 医薬分業率19)の上位 14 都道県中, 3 都県の みが全国平均取扱枚数よりも少なかつた，当該デー 夕は都道府県単位のものであるため, 市区町村単位 における実状は不明であるものの，過疎地域や医薬 分業率が高い地域の院外処方せん枚数に対する薬局 薬剂師数は, 全国平均を下回る人数しか存在してい ない市区町村が多いことが推察された。一方，今後 の地域包括ケアシステムの中での薬局薬剤師の必要 数については, 市区町村人口や院外処方せん枚数か らのみの評価だけでなく，在宅対応や健康サポート 体制の構築を含めた評価を取り入れることが必要に なろう。

地域包括ケアシステムにおいて，薬局がかかりつ け薬剂師・薬局としての機能に加え, 健康サポート 機能を発揮していくことが期待されている．近年， 健康サポート機能を有する薬局は「健康サポート薬 局」として公表され，2017 年 12 月末において，届 出数は全国で 705 件であった. ${ }^{21)}$ 約 6 万店舗に上る 薬局の中で, 健康サポート薬局は $1 \%$ 程度であり, 人口当たりの薬局薬剤師数が多い都市部の届出数に おいても，全薬局数に比べて著しく小さい。すなわ ち, 本調査で着目した薬局薬剂師の「数」以外にも, 地域包括ケアシステムの充実に向けて考慮すべき多 くの要因が存在していると考える.

本調査で用いた薬局薬剤師数は, 厚生労働省によ る医師・歯科医師・薬剤師調査を基にしたものであ る.そのため, 薬局薬剤師の勤務形態（常勤, 非常 勤）については考慮できていないが，本調査は薬局 薬剤師全体における人口との関連や過疎地域の分布 の特徵を明示している. 各地域における地域包括ケ 
アシステムの構築のためには，過疎地域を含め住民 が薬剤師による支援を十分に受けることができる体 制の存在は必須であり，薬局薬剤師が存在しない多 数の町村におけるその解消は課題の 1 つである．無 薬局薬剤師町村に限らず，薬局薬剤師の不足は各地 域での薬局薬剤師の活動の制限の要因になり得る. 本調査結果は, 薬局薬剤師の存在に関する特徵の現 状を示しており，今後の地域の医療サービスにおけ る薬局の課題を考える上で，有用な情報になること を期待したい.

\section{利益相反＼cjkstart開示すべき利益相反はない，}

\section{REFERENCES}

1) Ministry of Health, Labour and Welfare. "Kongo no koureisha jinkou no mitoushi.": 〈http: / / www.mhlw.go.jp / seisakunitsuite / bunya/hukushi_kaigo/kaigo_koureisha/chiikihoukatsu/dl/link1-1.pdf $>$, cited 30 November, 2017.

2) Ministry of Health, Labour and Welfare. "Kouteki kaigo hoken seido no genjou to kongo no yakuwari.": 〈http://www.mhlw.go. jp / file / 06-Seisakujouhou-12300000-Rouken kyoku/201602kaigohokenntoha_2.pdf $\rangle$, cited 11 December, 2017.

3) Mitsubishi UFJ Research and Consulting Co., Ltd. "Chiiki houkatsu care kenkyukai, Chiiki houkatsu care system no kouchiku ni okeru kongo no kentou no tame no ronten.": 〈http://www.murc.jp/uploads/2013/04/kou kai130423_01.pdf $\rangle$, cited 10 December, 2017.

4) Ministry of Health, Labour and Welfare. "Kanja no tame no yakkyoku vision.": 〈http:// www.mhlw.go.jp / file / 04-Houdouhappyou11121000-Iyakushokuhinkyoku-Soumuka/vision 1.pdf $\rangle$, cited 10 December, 2017.

5) Hasegawa Y., Sakamaki H., Yamazaki M., Iwatsuki S., Oide S., Kitada M., Ohashi Y., Suda K., Mochizuki M., Yakugaku Zasshi, 134, 277-291 (2014) .

6) Nakazawa Y., The Shinshu Med. J., 58, 291300 (2010).
7) Matsumoto M., Iryo To Shakai, 21, 97-107 (2011).

8) Ministry of Health, Labour and Welfare. "Ishi jukyu bunka kai.": 〈http://www. mhlw.go.jp/stf / shingi / other-isei.html?tid $=$ 318654>, cited 10 December, 2017.

9) Matsumoto M., Inoue K., Takeuchi K., Iryo To Shakai, 22, 103-112 (2012) .

10) Tajima H., Takakuda A., Kizu J., Kaneda M., Jpn. J. Pharm. Health Care Sci., 31, 375383 (2005).

11) Nakagawa S., Takase M., J. Jpn. Soc. Nurs. Res., 39, 105-113 (2016).

12) Pan American Health Organization, Epidemiol. Bull., 22, 3-4 (2001).

13) Sone M., Gendai Shakai Bunka Kenkyu, 44, 1-17 (2009).

14) Izutsu M., Suzuki E., Izutsu Y., Doi H., Acta Med. Okayama, 68, 101-110 (2014).

15) Fujiwara K., Yagahara A., Tanikawa T., Tani Y., Ohba H., Ogasawara K., Jpn. J. Radiol., 72, 970-977 (2016).

16) Sano H., Ishibashi Y., The Quarterly of Social Security Research., 45, 170-182 (2009).

17) Iida S., Sakamoto A., Jichi Med. Univ. J., 32, 29-41 (2009).

18) Ministry of Health, Labour and Welfare. "Kanja no tame no yakkyoku vision jitsugen no tame no jittai chousa houkoku.": 〈http:// www.mhlw.go.jp/file/06-Seisakujouhou-1112 0000-Iyakushokuhinkyoku/actionplan02.pdf $\rangle$, cited 10 December, 2017.

19) Japan Pharmaceutical Association. "Iyaku bungyou no shinchoku jyoukyou.": 〈http:// www.nichiyaku.or.jp/contents/bungyo/h28/ s/28sukei.pdf $\rangle$, cited 10 February, 2018.

20) Zenkoku kaso chiiki jiritsu sokushin renmei. "Kaso chiiki no databank.": 〈http://www. kaso-net.or.jp/kaso-db.htm $\rangle$, cited 10 February, 2018.

21) Ministry of Health, Labour and Welfare. "Kenkou support yakkyoku no todokedesu.": 〈http://www.mhlw.go.jp/file/06-Seisakujouhou-11120000-Iyakushokuhinkyoku / 171228. pdf $\rangle$, cited 10 February, 2018. 